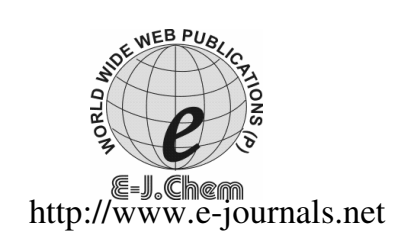

ISSN: 0973-4945; CODEN ECJHAO

E-Journal of Chemistry

2011, 8(3), 1280-1292

\title{
Solid-Phase Extraction with Diethyldithiocarbamate as Chelating Agent for Preconcentration and Trace Determination of Copper, Iron and Lead in Fruit Wine and Distilled Spirit by Flame Atomic Absorption Spectrometry
}

\author{
SAKSIT CHANTHAI*, NONGNOOT SUWAMART and \\ CHALERM RUANGVIRIYACHAI
}

Department of Chemistry and Center for Innovation in Chemistry Faculty of Science, Khon Kaen University, Khon Kaen 40002, Thailand

sakcha2@kku.ac.th

Received 19 June 2010; Accepted 2 September 2010

\begin{abstract}
Some heavy metals that present in wine and distilled spirit as background contamination are generally found at trace level particularly less than detection limit of common analytical techniques including flame atomic absorption spectrometry (FAAS). Thus, preconcentration method of the trace metals was developed. The optimum conditions for diethyldithiocarbamate (DDTC) complexes of $\mathrm{Cu}, \mathrm{Fe}$ and $\mathrm{Pb}$ were then investigated for the preconcentration step using $\mathrm{C}_{18}$ solid-phase extraction prior to measurement by FAAS. The preconcentration factor of 15 -fold was obtained with the appropriate ratio of sample volume used $(150 \mathrm{~mL})$ to $10 \mathrm{~mL}$ final volume giving their method recoveries of $\mathrm{Cu}, \mathrm{Fe}$ and $\mathrm{Pb}$ found in the ranges of $96.5-107,102-116$ and $91.7-107 \%$, respectively. Precision determinations $(n=10)$ for $0.1 \mathrm{mg} \mathrm{L}^{-1}$ of $\mathrm{Cu}, \mathrm{Fe}$ and $\mathrm{Pb}$ each in a model solution were $3.7,4.2$ and $7.1 \%$ RSD respectively. The detection limits (3SD) of $\mathrm{Cu}, \mathrm{Fe}$ and $\mathrm{Pb}$ were found to be $1.4,3.3$ and $5.7 \mu \mathrm{g} \mathrm{L}^{-1}$, respectively. The developed method was applied to ten samples of local fruit wines and five samples of distilled spirits, resulting in the ranges of 0.012-0.80 and 0.12-8.8 $\mathrm{mg} \mathrm{L}^{-1}$ for $\mathrm{Cu}$; 0.18-3.4 and 0.036-0.29 mg L $\mathrm{mg}^{-1}$ for $\mathrm{Fe}$ and $0.0070-0.053$ and $0.014-0.026 \mathrm{mg} \mathrm{L}^{-1}$ for $\mathrm{Pb}$, respectively. Therefore, the method is simple and inexpensive for routine analysis of the trace metals in these samples to overcome limit of detection of the instrument used.
\end{abstract}

Keywords: Fruit wine, Distilled spirit, Diethyldithiocarbamate, Solid-phase extraction, FAAS, Preconcentration 


\section{Introduction}

Fruit wines can be widely produced and consumed as alcoholic beverage throughout Thailand. Wine that made from fruits, such as mangosteen, longan, etc. must be identified by the fruits used, for instance, mangosteen wine, longan wine and so on. Distilled spirit is also an alcoholic one usually produced from rice wine or so-called "Satho". Daily consumption of wine and distilled spirit in moderate quantities may contribute significantly to the requirements of human organism for essential elements such as $\mathrm{Cu}$ and $\mathrm{Fe}$. But some metals such as $\mathrm{Pb}$ and $\mathrm{As}$ are known to be potentially toxic ${ }^{1-5}$. Analysis of certain elements in wine and distilled spirit is thus of interest due to their toxicity in case of excessive intake.

Most countries have specific legislation concerning the maximum permissible content of some metals, especially $\mathrm{Cu}, \mathrm{Fe}, \mathrm{Pb}$ and $\mathrm{As}$, in wine and distilled spirit ${ }^{6-9}$. Thai industrial standards institute (TISI) has been responsible for quality control of these local products in terms of limiting concentrations of the heavy metals normally found in wine and distilled spirit. The method proposed by the association of official analytical chemistry (AOAC) and/or other methods for the determination of $\mathrm{Cu}, \mathrm{Fe}, \mathrm{Pb}$ and $\mathrm{As}$ in wine and distilled spirit have been used ${ }^{10-18}$. Generally, determination of metals in beverage samples can be done by various instrumental techniques ${ }^{19-31}$. Flame atomic absorption spectrometry (FAAS) is the most commonly used technique for the metals determination. However, there are some difficulties to determine a trace level of heavy metals in beverage samples. First, it is a very low concentration of heavy metals, which may be lower than detection limit of many techniques including FAAS. The second one is the interfering effect of some matrices present in the samples. Direct FAAS determination of heavy metals in wine has been reported strong matrix interference especially in the case of red wines. Therefore, preliminary sample digestion is still recommended. Moreover, direct aspiration of wine and distilled spirit can cause flame fluctuations and accumulation of solid deposits on the burner head. Sometimes, the acids used for sample digestion may cause inaccuracies in method, which is based on external calibration with dilute aqueous standard solution. Thus, preconcentration method is still needed to improve the detection limit and some extent of selectivity for the determination by FAAS ${ }^{31-37}$. Solid-phase extraction (SPE) has been widely used for the preconcentration/ separation of trace metals and clean up or removal of matrix interference in aqueous samples ${ }^{38-43}$. As chelating agent, sodium diethyldithiocarbamate (DDTC) has a strong tendency to form stable heavy metal complexes. At the same time, it does not react with alkali, alkaline earth elements and some other metals. SPE method can be preconcentrated and separated the metalDDTC from a large excess of other matrix interferences in several samples by using a $\mathrm{C}_{18}$ column which exhibits a very strong retention to non-polar derivatives of the target metals ${ }^{44-47}$.

For the quality control of trace amounts of $\mathrm{Fe}, \mathrm{Cu}, \mathrm{Pb}$ and $\mathrm{As}$ in local thai fruit wine and distilled spirit samples under TISI legislation. Since ultratrace analysis of As in these samples can be done without preconcentration by HG-AAS ${ }^{48}$. The aim of the present study is to investigate simple and accurate method that is suitable for routine application for $\mathrm{Cu}$, $\mathrm{Fe}$ and $\mathrm{Pb}$ determinations in these samples by FAAS using DDTC as chelating agent associated with $\mathrm{C}_{18}$ solid-phase extraction for the preconcentration.

\section{Experimental}

All of reagents used were analytical reagent grade. The AAS standard solutions $\left(1,000 \mathrm{mg} \mathrm{L}^{-1}\right)$ of $\mathrm{Cu}, \mathrm{Fe}$ and $\mathrm{Pb}$ were obtained from Carlo Erba (Italy). Hydrochloric acid, absolute ethanol, 
sodium acetate, sodium citrate dihydrate, sodium diethyldithiocarbamate and sodium hydroxide were also from Carlo Erba (Italy). Nitric acid 65\% (w/v) was obtained from Merck (Germany). Di-sodium hydrogen phosphate anhydrous was obtained from Fluka (Switzerland). Hydrogen peroxide was of Ajex Chemical (Australia). Acetic acid was of Analar (England). All aqueous solutions were prepared with de-ionized water (Milli Q Millipore $18.2 \mathrm{M} \Omega \mathrm{cm}^{-1}$ resistivity) by simplicity water purification system, model simplicity 185, Millipore Corporation (USA).

\section{Instruments and apparatus}

An atomic absorption spectrometer of the Perkin-Elmer instruments (USA), model A analyst 100, AA win lab software was used in association with a 10-cm long slot burner head, hallow cathode lamp and air/acetylene flame. The spectra of the metal complexes were obtained by UV-visible spectrophotometer, model Agilent 8453 (Germany) equipped with a $1 \mathrm{~cm}$ quartz cell. $\mathrm{pH}$ measurement was performed on $\mathrm{pH}$ meter from Denver Instrument, model 251 (USA). The $\mathrm{C}_{18}$ cartridge $(500 \mathrm{mg}$ ) was obtained from Supelco (USA). All glassware were cleaned by soaking in $10 \%(\mathrm{v} / \mathrm{v}) \mathrm{HNO}_{3}$ overnight and rinsed three times with de-ionized water prior to use.

FAAS instrument for all determinations of $\mathrm{Cu}(324.8 \mathrm{~nm}, 0.7 \mathrm{~nm}$ slit width), $\mathrm{Fe}(248.3 \mathrm{~nm}$, $0.2 \mathrm{~nm}$ slit width) and $\mathrm{Pb}(283.3 \mathrm{~nm}, 0.7 \mathrm{~nm}$ slit width) was operated at the optimum conditions suggested by the manufacturer's manual, except some conditions such as air flow rate $\left(5 \mathrm{~mL} \mathrm{~min}^{-1}\right)$, acetylene flow rate $\left(2.5 \mathrm{~mL} \mathrm{~min}^{-1}\right)$ and sample flow rate $\left(7 \mathrm{~mL} \mathrm{~min}^{-1}\right)$ were re-optimized in this study. The AAS measurement was set as background corrected atomic absorption mode.

\section{Wine and distilled spirit samples}

Ten kinds of Thai fruit wines were purchased from local market in Khon Kaen province, Thailand. These fruit wines are locally produced by small holders through out Thailand and are available in the market. Five red wines were made from its color fruit materials including black galingale (RW01), Indian mulberry (RW02), mangosteen (RW03), maow (RW04) and bel fruit (RW05). Five white wines were also made from its fruits including longan (WW01), Indian gooseberry (WW02 and WW03), black glutinous rice (WW04) and pineapple (WW05). In case of distilled spirit samples, all of five samples were made from fermented rice as based materials including Kang Koaw (DS01), Bau Yai (DS02), Ta-Tiang (DS03), Pla-Mungkorn (DS04) and Bang Yikun (DS05). These wine samples were kept cool in refrigerator before use, while distilled spirit samples were stored in room temperature.

\section{Preparation of standard solutions}

A working solution of $50 \mathrm{mg} \mathrm{L}^{-1} \mathrm{Cu}$ was prepared by diluting $5 \mathrm{~mL}$ of its stock solution $\left(1,000 \mathrm{mg} \mathrm{L}^{-1}\right)$ to $100 \mathrm{~mL}$ with de-ionized water. For working solutions of $\mathrm{Fe}$ and $\mathrm{Pb}$ were daily prepared in the same manner. The calibration curve was established using the standard solution prepared in $3 \mathrm{~mol} \mathrm{~L}^{-1} \mathrm{HNO}_{3}$ by dilution from the working solutions and not introduced to the preconcentration procedure. The standard solution of $\mathrm{Cu}$ was contained $0.5,1.0,1.5,3.0$ and $5.0 \mathrm{mg} \mathrm{L}^{-1}$ and Fe was contained $0.5,1.5,3.0,5.0,10$ and $15 \mathrm{mg} \mathrm{L}^{-1}$, and $\mathrm{Pb}$ was contained $0.5,1.0,1.5,3.0$ and $5.0 \mathrm{mg} \mathrm{L}^{-1}$, respectively. Their standard solution was determined by FAAS.

\section{Preparation of $C_{18}$ cartridge}

The $\mathrm{C}_{18}$ sorbent packing material was firstly washed by passing $5 \mathrm{~mL}$ of $3 \mathrm{~mol} \mathrm{~L}^{-1} \mathrm{HNO}_{3}$ solutions twice in order to remove trace metals adsorbed on the packing material. 
Then, the cartridges were rinsed with $5 \mathrm{~mL}$ of deionized water twice and they were activated by washing with $5 \mathrm{~mL}$ of ethanol twice and rinsed with $5 \mathrm{~mL}$ of deionized water twice. At the beginning of next analysis cycle, the cartridge was rinsed with deionized water, washed with ethanol and again rinsed with deionized water as the same manner described.

\section{Metal-DDTC complex and preconcentration}

Performance of the $\mathrm{C}_{18}$ cartridge was tested with model solutions prior to its application to real samples. Trace metals of $\mathrm{Cu}, \mathrm{Fe}$ and $\mathrm{Pb}$ were complexed with DDTC under optimized conditions prior to preconcentration step by SPE method. The parameters that influence the preconcentration of these elements such as $\mathrm{pH}$, eluent concentration were also optimized.

\section{Effect of DDTC concentration}

A $0.01 \mathrm{~mol} \mathrm{~L}^{-1}$ DDTC solution was prepared by dissolving a required amount of sodium diethyldithiocarbamate (MW $225.23 \mathrm{~g} \mathrm{~mol}^{-1}$ ) in deionized water. The DDTC solution was prepared daily. Various concentrations of DDTC were also carried out. The DDTC concentration was investigated in the range of $1.0 \times 10^{-4}-2.0 \times 10^{-2} \mathrm{~mol} \mathrm{~L}^{-1}$ while $3 \mathrm{~mol} \mathrm{~L}^{-1}$ $\mathrm{HNO}_{3}$ was used in an elution step of the metal-DDTC complexes.

\section{Effect of $p H$}

Citric acid phosphate buffer solution was prepared by adding an appropriate volume of $0.1 \mathrm{~mol} \mathrm{~L}^{-1}$ citric acid to $0.2 \mathrm{~mol} \mathrm{~L}^{-1}$ di-sodium hydrogen phosphate solution for $\mathrm{pH} 3-8$. Buffer solutions pH 2 and 9 were prepared by using $0.1 \mathrm{~mol} \mathrm{~L}^{-1}$ citrate buffer solution and $0.2 \mathrm{~mol} \mathrm{~L}^{-1}$ phosphate buffer solution, respectively, The $\mathrm{pH}$ of the solution was adjusted with $3 \mathrm{~mol} \mathrm{~L}^{-1}$ $\mathrm{NaOH}$ or $3 \mathrm{~mol} \mathrm{~L}^{-1} \mathrm{HNO}_{3}$ until to get the desirable $\mathrm{pH}$.

The model solution $(20 \mathrm{~mL})$, containing $5.0 \mathrm{mg} \mathrm{L}^{-1} \mathrm{Cu}$ was prepared by diluting the working solution of $\mathrm{Cu}$ with each $\mathrm{pH}$ of citric phosphate buffer solutions ( $\mathrm{pH}$ 2-9). Each $\mathrm{pH}$ of their model solutions was added with $1 \mathrm{~mL}$ of $0.01 \mathrm{~mol} \mathrm{~L}^{-1}$ DDTC to form the metalDDTC complex. After $10 \mathrm{~min}$, the solution was loaded into the $\mathrm{C}_{18}$ cartridge. The flow of sample solution through the column was gravitationally performed. After finishing passage of the solution, the cartridge was washed with $5 \mathrm{~mL}$ of deionized water twice. The metals were eluted with ethanol into $20 \mathrm{~mL}$ volumetric flask and diluted to the mark with ethanol. For model solution of $\mathrm{Fe}$ and $\mathrm{Pb}$ were prepared and investigated as the same manner of $\mathrm{Cu}$. The UV-Visible absorption spectra of these metal-DDTC complexes were recorded from 200-600 nm by running the UV Visible absorption spectrometer in scan mode.

\section{Effect of time for complexation}

This parameter was studied at 5, 7 and $10 \mathrm{~min}$, respectively. The experiment was followed in the same manner as done with the effect of $\mathrm{pH}$.

\section{Effect of the eluent concentration}

A $3 \mathrm{~mol} \mathrm{~L}^{-1} \mathrm{HNO}_{3}$ was used as an eluent, which was prepared by appropriate dilution of concentrate nitric acid with deionized water. The model solution $(20 \mathrm{~mL})$, containing $5.0 \mathrm{mg} \mathrm{L}^{-1}$ $\mathrm{Fe}$ and $2.5 \mathrm{mg} \mathrm{L}^{-1} \mathrm{Cu}$ and $\mathrm{Pb}$, was prepared by pipetting $2 \mathrm{~mL}$ of the working solution of $\mathrm{Fe}$ and $1 \mathrm{~mL}$ of the working solution of $\mathrm{Cu}$ and $\mathrm{Pb}$ into $20 \mathrm{~mL}$ volumetric flask. Then, diluted with citric phosphate buffer solution pH 6 to the mark and $5 \mathrm{~mL}$ of $0.01 \mathrm{~mol} \mathrm{~L}^{-1}$ DDTC was added. After $5 \mathrm{~min}$, the solution was loaded into the cartridge. Afterward, the cartridge was washed with $5 \mathrm{~mL}$ of deionized water twice. The metals were recovered with various concentration of $\mathrm{HNO}_{3}$ $\left(1,2,3,4\right.$ and $\left.5 \mathrm{~mol} \mathrm{~L}^{-1}\right)$ into $10 \mathrm{~mL}$ volumetric flask and made the final volume to $10 \mathrm{~mL}$. The metal concentrations in the final solution were determined by FAAS. 


\section{Effect of interfering ions}

The model solutions $(20 \mathrm{~mL})$, containing $1.0 \mathrm{mg} \mathrm{L}^{-1}$ of $\mathrm{Cu}, \mathrm{Fe}$ and $\mathrm{Pb}$ in citric phosphate buffer solution, were mixed with each of matrix ions; including $100 \mathrm{mg} \mathrm{L}^{-1} \mathrm{Na}^{+}, \mathrm{K}^{+}$and $\mathrm{Mg}^{2+}$, $20 \mathrm{mg} \mathrm{L}^{-1} \mathrm{Li}^{+}, \mathrm{Ba}^{2+}, \mathrm{Zn}^{2+}, \mathrm{Mn}^{3+}$ and $\mathrm{Al}^{3+}$ and $2 \mathrm{mg} \mathrm{L}^{-1} \mathrm{Ni}^{2+}, \mathrm{Cr}^{3+}$ and $\mathrm{Sn}^{4+}$, respectively. Their solution was carried out in the same procedure as described above by using $3 \mathrm{~mol} \mathrm{~L}^{-1} \mathrm{HNO}_{3}$ and $1.0 \times 10^{-2} \mathrm{~mol} \mathrm{~L}^{-1}$ DDTC as an eluent and chelating agent, respectively.

\section{Preparation of wine and distilled spirit samples}

Wine or distilled spirit $(50 \mathrm{~mL})$ was evaporated in drying oven at $100{ }^{\circ} \mathrm{C}$ until dryness. After cooling at room temperature, the residue was treated with various volume of conc. $\mathrm{HNO}_{3}$ or acid mixture (conc. $\mathrm{HNO}_{3}$ and $30 \% \mathrm{H}_{2} \mathrm{O}_{2}$ ). Afterwards, the mixture was heated on hot plate about $110{ }^{\circ} \mathrm{C}$ and $80{ }^{\circ} \mathrm{C}$ in hood for wine and distilled spirit, respectively. The mixture was therefore evaporated until dryness. Effect of sample volume was also studied. Wine and distilled spirit were prepared in the same manner as described above by various volumes in the range of 100-300 and 100-400 mL for wine and distilled spirit, respectively.

After the digested sample solution was cool down to room temperature, $10 \mathrm{~mL}$ of the citric phosphate solution was added to the residue and then the solution was filtered through Whatman filter paper No.41. Afterward, these solutions were adjusted to $\mathrm{pH} 6$ with a dropwise of 3 mol L ${ }^{-1} \mathrm{NaOH}$ solution. Then, the preconcentration procedure; using $3 \mathrm{~mol} \mathrm{~L}^{-1}$ $\mathrm{HNO}_{3}$ and $1.0 \times 10^{-2} \mathrm{~mol} \mathrm{~L}^{-1}$ DDTC as an eluent and chelating agent, respectively was applied to the samples (10-mL final volume) prior to FAAS measurement.

In addition, the residue of samples digested by acid was also dissolved with deionized water, then the sample solution was filtered through Whatman filter paper No.41 and made the final volume to $10 \mathrm{~mL}$ with deionized water prior to FAAS measurement without using the precencentration step.

\section{Results and Discussion}

\section{Metal-DDTC complex and preconcentration}

The optimized conditions including $\mathrm{pH}$, reagent concentrations and matrix effect for the quantitative preconcentration were established by using model solutions. The $\mathrm{pH}$ of the test solutions is one of the important parameters affecting the efficiency of DDTC when reacts with metals and forms uncharged metal-DDTC complexes. Thus, this parameter was investigated in the $\mathrm{pH}$ range of 2-9 by employing buffer solutions according to the desired $\mathrm{pH}$. As shown Figure 1, the absorbance of each metal-DDTC complex at its maximum wavelength $(208 \mathrm{~nm}$, $344 \mathrm{~nm}$ and $432 \mathrm{~nm}$ for Pb-DDTC, Fe-DDTC and Cu-DDTC, respectively) was plotted as a function of $\mathrm{pH}$. It was found that $\mathrm{pH}$ in the range of 5-9, 6-7 and 6-8 was the highest absorption for $\mathrm{Cu}, \mathrm{Fe}$ and $\mathrm{Pb}$, respectively. Based on the results observed, the working $\mathrm{pH}$ was chosen at 6 to fix the compromised conditions of all three elements.

The absorbance of the DDTC complex of $\mathrm{Cu}, \mathrm{Fe}$ and $\mathrm{Pb}$ at each maximum wavelength was plotted as a function time. It was found that absorbance was slightly different in the range of 5-10 min, indicating a complete reaction as shown in Figure 2. Therefore, the time course for their metal-DDTC complex formation was chosen within $5 \mathrm{~min}$.

Since uncharged metal-DDTC complexes are adsorbed onto the adsorbent packing material in $\mathrm{C}_{18}$ cartridges, elution of metals must imply the metal-DDTC destruction. Previous report has shown that AAS encounter the problem of the presence of a complex organic matrix that causes severe suppression of analyte signal ${ }^{35-37}$. Thus, in this study, a nitric acid solution was selected for the elution of the metal ions. 


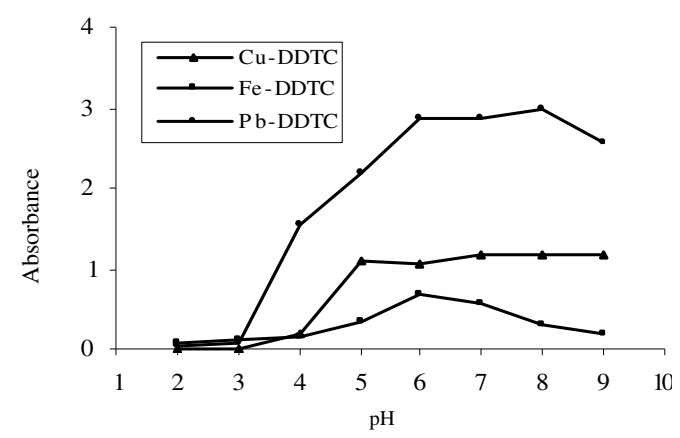

Figure 1. Effect of $\mathrm{pH}$ on the absorbance of metal-DDTC complex; $5 \mathrm{mg} \mathrm{L}^{-1} \mathrm{Cu}, \mathrm{Fe}$ and $\mathrm{Pb}$ $(n=6)$

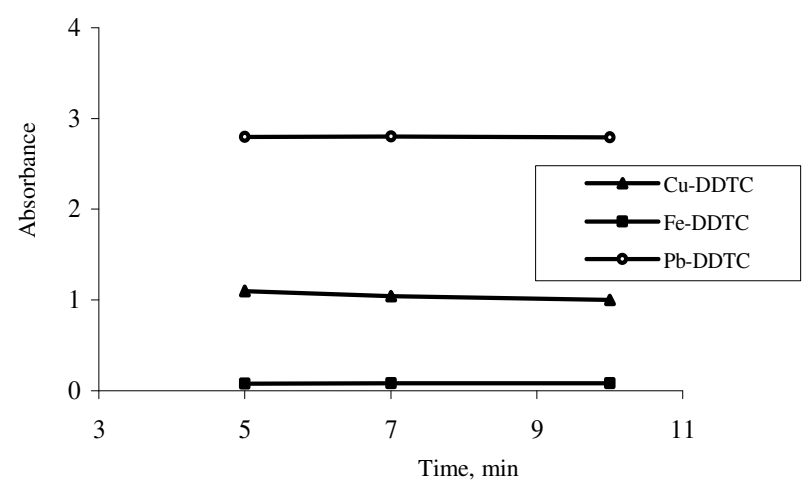

Figure 2. Effect of reaction time on the absorbance of metal-DDTC complex; $5 \mathrm{mgL}^{-1} \mathrm{Cu}$, $\mathrm{Fe}$ and $\mathrm{Pb}(n=6)$

The recoveries of the metals increased with an increasing the concentration of $\mathrm{HNO}_{3}$ and reached a constant value over $98 \%$ at $3 \mathrm{~mol} \mathrm{~L}^{-1} \mathrm{HNO}_{3}$ (as shown in Figure 3 and Table 1). From the results, the experimental studies were carried out using $3 \mathrm{~mol} \mathrm{~L}^{-1} \mathrm{HNO}_{3}$ as an eluent.

The influence of DDTC concentration on the recovery of the examined metal ions was investigated in the range of $1.0 \times 10^{-4}-2.0 \times 10^{-2} \mathrm{~mol} \mathrm{~L}^{-1}$ using the buffered model solution containing $5 \mathrm{mg} \mathrm{L}^{-1}$ of $\mathrm{Cu}$ and $\mathrm{Pb}$ and $10 \mathrm{mg} \mathrm{L}^{-1}$ of $\mathrm{Fe}$. As shown in Figure 4, the DDTC concentration is suitable in the range of $5.0 \times 10^{-3}$ to $2.0 \times 10^{-2} \mathrm{~mol} \mathrm{~L}^{-1}$. Thus, the DDTC concentration of $1.0 \times 10^{-2} \mathrm{~mol} \mathrm{~L}^{-1}$ was used for determination of all three elements.

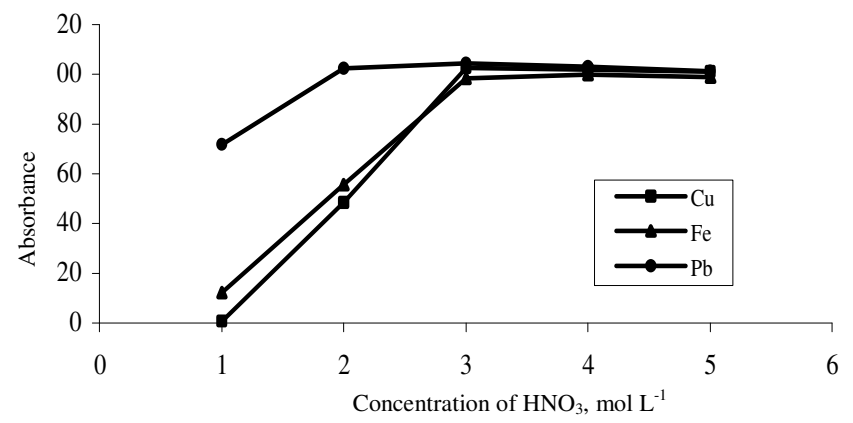

Figure 3. Effect of $\mathrm{HNO}_{3}$ concentration as eluent on the recovery of $5 \mathrm{mg} \mathrm{L}^{-1} \mathrm{Fe}$ and $2.5 \mathrm{mg} \mathrm{L}^{-1}$ of $\mathrm{Cu}$ and $\mathrm{Pb}(n=6)$ 


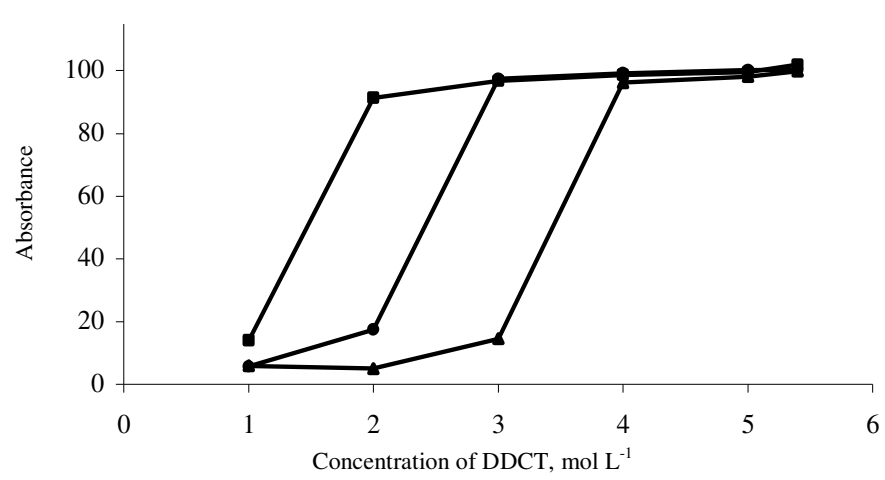

Figure 4. Effect of DDTC concentration on the recovery of $5 \mathrm{mg} \mathrm{L}^{-1} \mathrm{Fe}$ and $2.5 \mathrm{mg} \mathrm{L}^{-1}$ of $\mathrm{Cu}$ and $\mathrm{Pb}(n=6)$

Table 1. Recovery of $\mathrm{Cu}, \mathrm{Fe}$ and $\mathrm{Pb}$ determination in each fraction $(10 \mathrm{~mL})$ of the analyte elution $(n=6)$

\begin{tabular}{ccccc}
\hline $\begin{array}{c}\text { Concentration } \\
\text { of } \mathrm{HNO}_{3}, \mathrm{~mol} \mathrm{~L}^{-1}\end{array}$ & $\begin{array}{c}\text { Efluent, analyte } \\
\text { elution }\end{array}$ & \multicolumn{3}{c}{ Recovery, $\% \pm$ S.D. } \\
\cline { 3 - 5 } & & $\mathrm{Cu}$ & $\mathrm{Fe}$ & $\mathrm{Pb}$ \\
\hline 1.0 & Fraction 1 & $0.60 \pm 0.001$ & $12.2 \pm 0.034$ & $71.7 \pm 0.062$ \\
& Fraction 2 & $11.7 \pm 0.012$ & $23.5 \pm 0.029$ & $25.0 \pm 0.048$ \\
& Fraction 3 & $18.5 \pm 0.019$ & $27.9 \pm 0.016$ & n.d. \\
2.0 & Fraction 1 & $48.4 \pm 0.017$ & $55.6 \pm 0.033$ & $102 \pm 0.094$ \\
& Fraction 2 & $44.5 \pm 0.038$ & $42.6 \pm 0.051$ & N.D. \\
& Fraction 3 & n.d. & n.d. & n.d. \\
3.0 & Fraction 1 & $103 \pm 0.064$ & $98.7 \pm 0.103$ & $104 \pm 0.102$ \\
& Fraction 2 & n.d. & n.d. & n.d. \\
& Fraction 3 & n.d. & n.d. & n.d. \\
4.0 & Fraction 1 & $102 \pm 0.028$ & $99.4 \pm 0.091$ & $103 \pm 0.070$ \\
& Fraction 2 & n.d. & n.d. & n.d. \\
& Fraction 3 & n.d. & n.d. & n.d. \\
& Fraction 1 & $101 \pm 0.021$ & $98.1 \pm 0.073$ & $101 \pm 0.057$ \\
& Fraction 2 & n.d. & n.d. & n.d. \\
& Fraction 3 & n.d. & n.d. & n.d. \\
\hline
\end{tabular}

Model solution was used consisting of $5 \mathrm{mg} \mathrm{L}^{-1} \mathrm{Fe}$, and $2.5 \mathrm{mg} \mathrm{L}^{-1}$ of Cu and Pb. n.d., not detectable

Effect of interfering ions

Since determination of trace level of metal ions in local wine and distilled spirit samples is the main objective. The common problem in the FAAS determination of the trace metals is usually accounted for interferences from the matrices of samples. In this study, the influence of some interfering ions was investigated by concentration choice based on the literature values found in beverage samples. The results are summarized in Table 2, it is concluded that alkaline and alkaline earth metals are almost not retained through the SPE cartridge due to low stability constant of the DDTC used. Also, some of the transition metals at $\mathrm{mg} \mathrm{L}^{-1}$ levels caused an error with less than $\pm 5 \%$ associated with recoveries of the interested metals under the experimental conditions. This results show that the proposed preconcentration method could be applied to both wine and distilled spirit samples containing some transition metals. 
Table 2. Effect of some matrix ions on the recovery of $\mathrm{Cu}, \mathrm{Fe}$ and $\mathrm{Pb}(n=5)$

\begin{tabular}{|c|c|c|c|c|c|}
\hline \multirow[t]{2}{*}{ Ion } & \multirow[t]{2}{*}{ Added as } & \multirow{2}{*}{$\begin{array}{l}\text { Ion concentration, } \\
\mathrm{mg} \mathrm{L}^{-1}\end{array}$} & \multicolumn{3}{|c|}{ Recovery, $\% \pm$ S.D. } \\
\hline & & & $\mathrm{Cu}$ & $\mathrm{Fe}$ & $\mathrm{Pb}$ \\
\hline $\mathrm{Na}^{+}$ & $\mathrm{NaCl}$ & 100 & $102 \pm 0.007$ & $106 \pm 0.007$ & $100 \pm 0.004$ \\
\hline $\mathrm{K}^{+}$ & $\mathrm{KCl}$ & 100 & $103 \pm 0.032$ & $97.4 \pm 0.069$ & $99.0 \pm 0.039$ \\
\hline $\mathrm{Mg}^{2+}$ & $\mathrm{Mg}\left(\mathrm{NO}_{3}\right)_{2}$ & 100 & $101 \pm 0.009$ & $100 \pm 0.025$ & $102 \pm 0.002$ \\
\hline $\mathrm{Li}^{+}$ & $\mathrm{LiNO}_{3}$ & 20 & $104 \pm 0.004$ & $98.7 \pm 0.043$ & $108 \pm 0.001$ \\
\hline $\mathrm{Ba}^{2+}$ & $\mathrm{BaCl}_{2}$ & 20 & $101 \pm 0.006$ & $101 \pm 0.006$ & $114 \pm 0.011$ \\
\hline $\mathrm{Zn}^{2+}$ & $\mathrm{ZnCl}_{2}$ & 20 & $114 \pm 0.013$ & $105 \pm 0.054$ & $105 \pm 0.027$ \\
\hline $\mathrm{Mn}^{2+}$ & $\mathrm{MnCl}_{2}$ & 20 & $105 \pm 0.013$ & $96.9 \pm 0.007$ & $101 \pm 0.006$ \\
\hline $\mathrm{Al}^{3+}$ & $\mathrm{AlCl}_{3}$ & 20 & $104 \pm 0.009$ & $99.2 \pm 0.025$ & $95.2 \pm 0.021$ \\
\hline $\mathrm{Ni}^{2+}$ & $\mathrm{Ni}\left(\mathrm{NO}_{3}\right)_{2}$ & 2 & $109 \pm 0.005$ & $110 \pm 0.015$ & $97.8 \pm 0.026$ \\
\hline $\mathrm{Cr}^{3+}$ & $\mathrm{Cr}\left(\mathrm{NO}_{3}\right)_{3}$ & 2 & $98.7 \pm 0.007$ & $97.7 \pm 0.002$ & $96.5 \pm 0.015$ \\
\hline $\mathrm{Sn}^{4+}$ & $\mathrm{SnCl}_{4}$ & 2 & $97.6 \pm 0.031$ & $99.3 \pm 0.006$ & $97.1 \pm 0.018$ \\
\hline
\end{tabular}

The model solution was used consisting of $1.0 \mathrm{mg} \mathrm{L}^{-1} \mathrm{Cu}, \mathrm{Fe}$ and $\mathrm{Pb}$

\section{Sample preparation}

In this case preliminary evaporation of ethanol is performed in order to avoid strong bubble formation while digestion procedure proceeds and to ensure better conditions for a complete mineralization of organic matter in the sample. Wine and distilled spirit samples were treated with various volumes of acid. The results are shown in Table 3 . It was found that the recoveries of $\mathrm{Pb}$ were quantitative (higher than $95 \%$ ) for all ratios of sample: $\mathrm{HNO}_{3}: \mathrm{H}_{2} \mathrm{O}_{2}$ in wine and distilled spirit samples. Some ratios of sample: $\mathrm{HNO}_{3}: \mathrm{H}_{2} \mathrm{O}_{2}$ given the recoveries of $\mathrm{Cu}$ and $\mathrm{Fe}$ were lower than 95\%; that is in the ratio of 10:3: 0 for $\mathrm{Cu}$ in wine, 10: 3: $0.5 \mathrm{For} \mathrm{Cu}$ and $\mathrm{Fe}$ in wine and 50: 0: 0 for $\mathrm{Cu}$ and $\mathrm{Fe}$ in distilled spirit. From this result, the ratios of 10: 4: 0 and 50: 1: 0 were chosen for all elements determination in wine and distilled spirit samples, respectively.

Table 3. Recovery of $\mathrm{Cu}, \mathrm{Fe}$ and $\mathrm{Pb}$ in wine and distilled spirit samples using various ratios of sample and oxidizing agent $(n=3)$

\begin{tabular}{lcccc}
\hline \multirow{2}{*}{ Beverage } & \multirow{2}{*}{ Sample: $\mathrm{HNO}_{3}: \mathrm{H}_{2} \mathrm{O}_{2}$} & \multicolumn{3}{c}{ Recovery, \% \pm S.D. } \\
\cline { 3 - 5 } & $10: 3: 0$ & $\mathrm{Cu}$ & $\mathrm{Fe}$ & $\mathrm{Pb}$ \\
\hline Wine & $10: 4: 0$ & $101 \pm 0.002$ & $100 \pm 0.027$ & $96.6 \pm 0.022$ \\
& $10: 5: 0$ & $103 \pm 0.003$ & $99.1 \pm 0.032$ & $98.1 \pm 0.003$ \\
& $10: 3: 0.5$ & $94.2 \pm 0.019$ & $91.5 \pm 0.059$ & $98.5 \pm 0.041$ \\
& $10: 4: 0.5$ & $111 \pm 0.005$ & $109 \pm 0.026$ & $97.3 \pm 0.008$ \\
Distilled spirit & $50: 0: 0$ & $89.0 \pm 0.028$ & $92.2 \pm 0.017$ & $95.2 \pm 0.005$ \\
& $50: 1: 0$ & $98.2 \pm 0.002$ & $108 \pm 0.080$ & $97.0 \pm 0.007$ \\
& $50: 2: 0$ & $97.6 \pm 0.021$ & $104 \pm 0.013$ & $101 \pm 0.010$ \\
& $50: 3: 0$ & $99.3 \pm 0.021$ & $112 \pm 0.093$ & $98.3 \pm 0.012$ \\
& $50: 5: 0$ & $97.6 \pm 0.010$ & $106 \pm 0.035$ & $96.7 \pm 0.002$ \\
\hline
\end{tabular}

Spiked samples were contained $0.1 \mathrm{mg} \mathrm{L}^{-1} \mathrm{Cu}$, Fe and $\mathrm{Pb}$.

The SPE technique is a common procedure for extraction and separation of ions from a large sample volume to obtain a high preconcentration factor. In this study, the influence of sample volume was investigated in the range of $50-400 \mathrm{~mL}$ of sample containing $0.1 \mathrm{mg} \mathrm{L}^{-1}$ of each metal ion. The results obtained from both standard curve method and standard addition method are listed in Table 4. It was found that the averaged recoveries of each 
element were higher than 97.9 and $96.1 \%$ for wine and distilled spirit, respectively. Therefore, the preconcentration of these metals was not affected by the sample volume between 100-300 and 100-400 mL for wine and distilled spirit, respectively. Thus, sample volume in this range could be used in the proposed procedures.

Table 4. Effect of sample volume on recovery of $\mathrm{Cu}, \mathrm{Fe}$ and $\mathrm{Pb}$ determination $(n=3)$

\begin{tabular}{|c|c|c|c|c|c|}
\hline \multirow[b]{2}{*}{ Beverage } & \multirow[b]{2}{*}{ Metal } & \multirow[b]{2}{*}{ 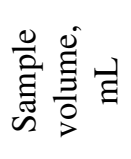 } & \multicolumn{2}{|c|}{ Concentration, $\mathrm{mg} \mathrm{L}^{-1}$} & \multirow[b]{2}{*}{$\begin{array}{c}\text { Recovery, } \\
\%\end{array}$} \\
\hline & & & $\begin{array}{l}\text { Standard curve } \\
\text { method }\end{array}$ & $\begin{array}{l}\text { Standard addition } \\
\text { method, } \\
\text { spiked } 0.1 \mathrm{mg} \mathrm{L}^{-1}\end{array}$ & \\
\hline \multirow[t]{9}{*}{ Wine } & \multirow[t]{3}{*}{$\mathrm{Cu}$} & 100 & $0.040 \pm 0.001$ & $0.142 \pm 0.008$ & 103 \\
\hline & & 200 & $0.039 \pm 0.004$ & $0.147 \pm 0.002$ & 108 \\
\hline & & 300 & $0.040 \pm 0.003$ & $0.158 \pm 0.003$ & 118 \\
\hline & \multirow[t]{3}{*}{$\mathrm{Fe}$} & 100 & $1.897 \pm 0.056$ & $1.996 \pm 0.031$ & 99.0 \\
\hline & & 200 & $1.876 \pm 0.069$ & $1.975 \pm 0.031$ & 98.2 \\
\hline & & 300 & $1.877 \pm 0.001$ & $1.983 \pm 0.014$ & 106 \\
\hline & \multirow[t]{3}{*}{$\mathrm{Pb}$} & 100 & n.d. & $0.098 \pm 0.007$ & 97.9 \\
\hline & & 200 & n.d. & $0.106 \pm 0.007$ & 107 \\
\hline & & 300 & n.d. & $0.101 \pm 0.003$ & 101 \\
\hline \multirow{12}{*}{$\begin{array}{l}\text { Distilled } \\
\text { spirit }\end{array}$} & \multirow[t]{4}{*}{$\mathrm{Cu}$} & 100 & $0.117 \pm 0.036$ & $0.225 \pm 0.010$ & 108 \\
\hline & & 200 & $0.105 \pm 0.011$ & $0.211 \pm 0.076$ & 106 \\
\hline & & 300 & $0.117 \pm 0.037$ & $0.213 \pm 0.034$ & 96.1 \\
\hline & & 400 & $0.123 \pm 0.054$ & $0.230 \pm 0.041$ & 104 \\
\hline & \multirow[t]{4}{*}{$\mathrm{Fe}$} & 100 & $0.033 \pm 0.004$ & $0.150 \pm 0.011$ & 117 \\
\hline & & 200 & $0.031 \pm 0.008$ & $0.133 \pm 0.008$ & 99.8 \\
\hline & & 300 & $0.032 \pm 0.021$ & $0.138 \pm 0.008$ & 106 \\
\hline & & 400 & $0.035 \pm 0.021$ & $0.136 \pm 0.015$ & 101 \\
\hline & \multirow[t]{4}{*}{$\mathrm{Pb}$} & 100 & $0.019 \pm 0.003$ & $0.124 \pm 0.009$ & 106 \\
\hline & & 200 & $0.016 \pm 0.006$ & $0.123 \pm 0.009$ & 107 \\
\hline & & 300 & $0.021 \pm 0.034$ & $0.133+0.004$ & 112 \\
\hline & & 400 & $0.022+0.011$ & $0.124+0.010$ & 102 \\
\hline
\end{tabular}

Consequently, suitable for the quantitative preconcentration by $\mathrm{SPE}$ of $\mathrm{Cu}, \mathrm{Fe}$ and $\mathrm{Pb}$ in this study was using $0.01 \mathrm{~mol} \mathrm{~L}^{-1}$ DDTC solution and $3 \mathrm{~mol} \mathrm{~L}^{-1} \mathrm{HNO}_{3}$ as chelating agent and eluent, respectively. The working $\mathrm{pH}$ was 6 to fix the compromised conditions for complexation of all three elements with DDTC. The ratio of sample: $\mathrm{HNO}_{3}$ for acid digestion was 10:3 and 50:1 for wine and distilled spirit sample, respectively. As shown in Table 5, good recovery for determination of model solution was contained $\mathrm{Cu}, \mathrm{Fe}$ and $\mathrm{Pb}$ using this proposed condition.

Table 5. Determination of $\mathrm{Cu}, \mathrm{Fe}$ and $\mathrm{Pb}$ contents using the developed method $(n=5)$

\begin{tabular}{|c|c|c|c|}
\hline \multirow{2}{*}{ Metal } & \multicolumn{2}{|c|}{ Concentration, $\mathrm{mg} \mathrm{L}^{-1}$} & \multirow{2}{*}{ Recovery, \% } \\
\hline & Taken & Found \pm S.D. & \\
\hline \multirow{2}{*}{$\mathrm{Cu}$} & 0.10 & $0.096+0.003$ & 96.0 \\
\hline & 0.50 & $0.511+0.009$ & 102 \\
\hline \multirow[t]{2}{*}{$\mathrm{Fe}$} & 0.10 & $0.104 \pm 0.012$ & 104 \\
\hline & 0.50 & $0.498+0.018$ & 99.6 \\
\hline \multirow[t]{2}{*}{$\mathrm{Pb}$} & 0.10 & $0.102+0.025$ & 102 \\
\hline & 0.50 & $0.530+0.219$ & 106 \\
\hline
\end{tabular}




\section{Analytical performance characteristics}

The accuracy and precision of the overall procedures (SPE and FAAS determination) are reported in terms of recovery (\%) and R.S.D.(\%), respectively, by determination of various amounts of these metal ions spiked to the samples used. The result in Table 6 shows good recoveries for $\mathrm{Cu}, \mathrm{Fe}$ and $\mathrm{Pb}$ determination of each with two spiked levels in wine and distilled spirit sample.

Table 6. Recovery of $\mathrm{Cu}, \mathrm{Fe}$ and $\mathrm{Pb}$ in the spiked sample determined by the developed procedure $(n=3)$

\begin{tabular}{|c|c|c|c|c|}
\hline \multirow{2}{*}{ Sample } & \multirow{2}{*}{ Metal } & \multicolumn{2}{|c|}{ Concentration, $\mathrm{mg} \mathrm{L}^{-1}$} & \multirow{2}{*}{ Recovery, \% } \\
\hline & & Taken & Found \pm S.D. & \\
\hline \multirow[t]{9}{*}{ Wine } & $\mathrm{Cu}$ & 0.00 & $0.024 \pm 0.001$ & - \\
\hline & & 0.05 & $0.072 \pm 0.006$ & 96.5 \\
\hline & & 1.00 & $0.989 \pm 0.026$ & 96.6 \\
\hline & $\mathrm{Fe}$ & 0.00 & $0.598 \pm 0.013$ & - \\
\hline & & 0.05 & $0.621 \pm 0.011$ & 116 \\
\hline & & 1.00 & $1.613 \pm 0.008$ & 102 \\
\hline & $\mathrm{Pb}$ & 0.00 & n.d. & - \\
\hline & & 0.02 & $0.018 \pm 0.001$ & 91.7 \\
\hline & & 0.50 & $0.510 \pm 0.007$ & 102 \\
\hline \multirow{9}{*}{ Distilled spirit } & $\mathrm{Cu}$ & 0.00 & $0.1215 \pm 0.004$ & - \\
\hline & & 0.05 & $0.1720+0.004$ & 101 \\
\hline & & 1.00 & $1.1023 \pm 0.007$ & 98.0 \\
\hline & $\mathrm{Fe}$ & 0.00 & $0.0360 \pm 0.005$ & - \\
\hline & & 0.05 & $0.0581+0.001$ & 110 \\
\hline & & 1.00 & $1.0653+0.003$ & 103 \\
\hline & $\mathrm{Pb}$ & 0.00 & $0.0262 \pm 0.003$ & - \\
\hline & & 0.02 & $0.0467+0.037$ & 103 \\
\hline & & 0.50 & $0.5602 \pm 0.105$ & 107 \\
\hline
\end{tabular}

n.d., not detectable

However, the precision (R.S.D.) for 10 replicate determinations of $0.1 \mathrm{mg} \mathrm{L}^{-1} \mathrm{Cu}, \mathrm{Fe}$ and $\mathrm{Pb}$ in model solutions were $3.7,4.2$ and $7.1 \%$, respectively. From these results, it is concluded that the procedure offers a good repeatability for all elements. The limits of detection were defined as the concentration equivalent to three times the standard deviation, $n=10$, of the blank solution (3SD). The values were $0.001 \mathrm{mg} \mathrm{L}^{-1}$ for $\mathrm{Cu}, 0.003 \mathrm{mg} \mathrm{L}^{-1}$ for $\mathrm{Fe}$ and $0.006 \mathrm{mg} \mathrm{L}^{-1}$ for $\mathrm{Pb}$. The limit of quantitation (10SD) was $0.005,0.012$ and $0.019 \mathrm{mg} \mathrm{L}^{-1}$ for $\mathrm{Cu}, \mathrm{Fe}$ and $\mathrm{Pb}$, respectively. The regression equation and correlation coefficient $\left(\mathrm{r}^{2}\right)$ for $\mathrm{Cu}$ was $\mathrm{y}=0.0458 \mathrm{x}+0.0005$ and 1.0000 , for Fe was $\mathrm{y}=0.0281 \mathrm{x}+0.0061$ and 0.9998 and for $\mathrm{Pb}$ was $\mathrm{y}=0.0084 \mathrm{x}-0.0003$ and 0.9994 , respectively. The preconcentration factor calculated from the ratio of sample volume used in this study $(150 \mathrm{~mL})$ to $10 \mathrm{~mL}$ final volume was 15 .

Table 7 shows the result of these metals determination in wine and distilled spirit samples that was prepared by acid digestion and SPE method comparing with acid digestion without SPE method using the sample of $150 \mathrm{~mL}$. It was observed that precision of using the SPE method was higher than that of without using one. Especially the determination of wine sample, it was found that using SPE method is better than without using one for $\mathrm{Cu}$ and $\mathrm{Pb}$ determination, since the content of $\mathrm{Cu}$ and $\mathrm{Pb}$ in wine is quite low. For the determination of $\mathrm{Fe}$ 
in wine sample, it was found that a slight difference in the results for both procedures was due to high $\mathrm{Fe}$ content in the sample used. Distilled spirit sample was slightly interfered with matrices and thus gave slightly different in the results for of both procedures. But at a very low level of metals using no SPE step these elements were not detectable, while the SPE did.

Table 7. Comparative determination of $\mathrm{Cu}, \mathrm{Fe}$ and $\mathrm{Pb}$ contents using the developed procedure with and without SPE method $(n=3)$

\begin{tabular}{|c|c|c|c|c|c|}
\hline \multirow[b]{2}{*}{ Sample } & \multirow[b]{2}{*}{ Metal } & \multicolumn{2}{|c|}{ Procedure with SPE } & \multicolumn{2}{|c|}{ Procedure without SPE } \\
\hline & & $\begin{array}{c}\text { Conc., } \\
\mathrm{mg} \mathrm{L}^{-1} \pm \mathrm{SD}\end{array}$ & $\begin{array}{c}\text { R.S.D, } \\
\%\end{array}$ & $\begin{array}{c}\text { Conc., } \\
\mathrm{mg} \mathrm{L}^{-1} \pm \mathrm{SD}\end{array}$ & $\begin{array}{c}\text { R.S.D, } \\
\%\end{array}$ \\
\hline \multirow[t]{3}{*}{ Red wine } & $\mathrm{Cu}$ & 0.012 & 8.4 & n.d. & n.d. \\
\hline & $\mathrm{Fe}$ & 2.911 & 1.2 & 3.014 & 3.40 \\
\hline & $\mathrm{Pb}$ & 0.052 & 9.6 & 0.032 & 127 \\
\hline \multirow[t]{3}{*}{ White wine } & $\mathrm{Cu}$ & 0.021 & 9.4 & 0.050 & 82.1 \\
\hline & $\mathrm{Fe}$ & 0.573 & 4.0 & 0.550 & 13.8 \\
\hline & $\mathrm{Pb}$ & 0.007 & 15 & n.d. & n.d. \\
\hline \multirow[t]{3}{*}{ Distilled spirit } & $\mathrm{Cu}$ & 0.135 & 3.7 & 0.153 & 11.2 \\
\hline & $\mathrm{Fe}$ & 0.245 & 4.9 & 0.320 & 17.2 \\
\hline & $\mathrm{Pb}$ & 0.018 & 11 & n.d. & n.d. \\
\hline
\end{tabular}

\section{Real sample analysis}

The SPE procedure for $\mathrm{Cu}, \mathrm{Fe}$ and $\mathrm{Pb}$ with DDTC on $\mathrm{C}_{18}$ cartridge was applied to local thai wine and distilled spirit samples. The results are given in Table 8 . The $\mathrm{Cu}$ contents found in wines and distilled spirits are ranged between $0.012-0.80 \mathrm{mg} \mathrm{L}^{-1}$ and $0.12-8.8 \mathrm{mg} \mathrm{L}^{-1}$, respectively. The Fe concentration found in this study was in the range of 0.18-3.4 and 0.036- $0.29 \mathrm{mg} \mathrm{L}^{-1}$ for wines and distilled spirits, respectively. That amount was lower than the upper permissible limit established by TCPS, which should be accounted at $15 \mathrm{mg} \mathrm{L}^{-1}$.

Table 8. Determination of $\mathrm{Cu}, \mathrm{Fe}$ and $\mathrm{Pb}$ in fruit wine and distilled spirit samples $(n=3)$

\begin{tabular}{cccc}
\hline \multirow{2}{*}{ Sample } & \multicolumn{3}{c}{ Concentration, mg L $\mathrm{m}^{-1} \pm \mathrm{SD}$} \\
\cline { 2 - 4 } & $\mathrm{Cu}$ & $\mathrm{Fe}$ & $\mathrm{Pb}$ \\
\hline RW 01 & $0.047 \pm 0.004$ & $0.74 \pm 0.001$ & $0.034 \pm 0.005$ \\
RW 02 & $0.084 \pm 0.002$ & $0.72 \pm 0.003$ & $0.0070 \pm 0.004$ \\
RW 03 & $0.022 \pm 0.008$ & $2.5 \pm 0.017$ & n.d. \\
RW 04 & $0.039 \pm 0.001$ & $1.9 \pm 0.891$ & n.d. \\
RW 05 & $0.049 \pm 0.005$ & $1.1 \pm 0.028$ & $0.012 \pm 0.002$ \\
WW 01 & $0.012 \pm 0.005$ & $3.4 \pm 0.153$ & n.d. \\
WW 02 & $0.80 \pm 0.049$ & $1.7 \pm 0.008$ & $0.053 \pm 0.001$ \\
WW 03 & $0.11 \pm 0.023$ & $1.6 \pm 0.254$ & $0.017 \pm 0.002$ \\
WW 04 & n.d. & $0.24 \pm 0.031$ & $0.0090 \pm 0.001$ \\
WW 05 & $0.055 \pm 0.011$ & $0.18 \pm 0.021$ & n.d. \\
DS 01 & $0.12 \pm 0.004$ & $0.036 \pm 0.007$ & $0.026 \pm 0.003$ \\
DS 02 & $8.8 \pm 0.102$ & $0.12 \pm 0.088$ & n.d. \\
DS 03 & $0.18 \pm 0.006$ & $0.10 \pm 0.018$ & $0.018 \pm 0.004$ \\
DS 04 & $1.6 \pm 0.053$ & $0.29 \pm 0.049$ & n.d. \\
DS 05 & $0.33 \pm 0.008$ & $0.076 \pm 0.005$ & n.d. \\
\hline
\end{tabular}


All analyzed wine and distilled spirit samples contained $\mathrm{Pb}$ contents lower than the upper value of TCPS, permissible limit is $0.2 \mathrm{mg} \mathrm{L}^{-1}$. In this study, $\mathrm{Pb}$ concentrations in wines were in the range of $0.0074-0.053 \mathrm{mg} \mathrm{L}^{-1}$, while $\mathrm{Pb}$ concentration in distilled spirits were in the range of $0.014-0.026 \mathrm{mg} \mathrm{L}^{-1}$. The $\mathrm{Pb}$ concentrations in some samples were not detectable due to it was lower than the method detection limit.

\section{Conclusion}

Copper, iron and lead determinations, based on acid digestion of sample and subsequent SPE, were investigated. The ratios of sample: conc. $\mathrm{HNO}_{3}$ that used for wine and distilled spirit digestion were 10:4 and 50:1 by volume, respectively. Optimized SPE conditions; $0.01 \mathrm{~mol} \mathrm{~L}^{-1}$ DDTC solution was added to digested sample for complexation. Then the complexes was sorbed onto $\mathrm{C}_{18}$ cartridge and eluted with 3 mol L-1 $\mathrm{HNO}_{3}$ that is adequate for preconcentration and separation of some interfering ions prior to FAAS measurement. Some interference ions caused an error with less than $\pm 5 \%$ associated with recoveries of the metal ions under the experimental conditions used. It is concluded that the proposed procedure, besides providing an increase in both sensitivity and selectivity, allows the separation of the interfering matrix, so that external calibration can be used resulting in a high precision. Based on the results at the highest concentration of $\mathrm{Cu}, \mathrm{Fe}$ and $\mathrm{Pb}$ in these samples can be calculated, suggesting an adequate intake in every day's life of alcoholic beverages.

\section{Acknowledgment}

Financial support from Center for Innovation in Chemistry (PERCH-CIC), Commission on Higher Education, Ministry of Education and the Hitachi Scholarship Foundation (Tokyo, Japan) is gratefully acknowledged.

\section{References}

1. Galani-Nikolakaki S, Kallithrakas-Kontos N and Katsanos A A, Sci Total Environ., 2002, 285(1-3), 155-163.

2. Lara R, Cerutti S, Salonia J A, Olsina R A and Martinez L D, Food Chem Toxicol., 2005, 43, 293-297.

3. Lazos E S and Alexakis A, Int J Food Sci Technol., 1989, 24, 39-46.

4. Guerrero M I, Herce-Pagliai C, Camean A M, Troncoso A M and Gonzalez A G, Talanta, 1997, 45(2), 379-386.

5. Kment P, Mihaljevic M, Ettler V, Sebek O, Strnad L and Rohlova L, Food Chem., 2005, 91(1), 157-165.

6. Sperkova J and Suchanek M, Food Chem., 2005, 93, 659-663.

7. Karadjova I, Izgi B and Gucer S, Spectrochim Acta B, 2002, 57(3), 581-590

8. Yaman M and Kaya G, Anal Chim Acta, 2005, 540, 77.

9. Ough C S, Crowell E A and Benz J, J Food Sci., 1982, 47, 825.

10. Lopez-Artiguez M, Camean A M and Repetto M, J AOAC Int., 1996, 79(5), 1191-1197.

11. Benitez P, Castro R and Barroso C G, Anal Chim Acta, 2002, 458, 197-202.

12. Paleologos E K, Giokas D L, Tzouwara-Karayanni S M and Karayannis M I, Anal Chim Acta, 2002, 458, 241-248.

13. Esparza I, Salinas I, Cabellero I, Santamaria C, Calvo I, Garcia-Mina J M and Fernandez J M, Anal Chim Acta., 2004, 524, 215.

14. Riganakos K A and Veltsistas P G, Food Chem., 2003, 82, 637-643.

15. Agrawal O, Sunita G and Gupta V K, J Chin Chem Soc., 1999, 46, 641. 
16. Lemos V A, de la Guardia M and Ferreira S L C, Talanta, 2002, 58, 475.

17. Frank J, Krachler M and Shotyk W, Anal Chim Acta, 2005, 530, 307.

18. Wangkarn S and Pergantis S A, J Anal At Spectrom., 1999, 14, 657.

19. Anjos M J, Lopes R T, de Jesus E F O, Moreira S, Barroso R C and Castro C R F, Spectrochim Acta B, 2003, 58, 2227-2232,

20. Dugo G, Pera L L, Pelicano T M, Bella G D and D'Imperio M, Food Chem., 2005, 91, 355 .

21. Elci L, Arslan Z and Tyson J F, Spectrochim Acta B, 2000, 55, 1109.

22. Tuzen M, Suylak M and Elci L, Anal. Chim. Acta, 2005, 548, 101-108.

23. Nascentes C C, Arruda M A Z, Nogueira A R A and Nobrega J A, Talanta, 2004, 64, 912.

24. Lima R, Leandro K C and Santelli R E, Talanta, 1996, 43, 997-983.

25. Cesur H, Turk J Chem., 2003, 27, 307.

26. Camel V, Spectrochim Acta B, 2003, 58, 1177.

27. Tarley C R T, Ferreira S L C and Arruda M A Z, J Microchem., 2004, 77, 163.

28. Kim Y S, G In, Han C W and Choi J M, J Microchem., 2005, 80, 151-157.

29. Bortoli A, Gerotto M, Marchiori M, Mariconti F, Palonta M and Troncon A, J Microchem., 1996, 54(4), 402-411.

30. Elci L, Sahin U and Oztas S, Talanta, 1997, 44(6), 1017-1023.

31. Jin Q, Su X, Liang F and Zhang H, J Microchem., 1999, 62, 316-327.

32. Cambell A D, Pure Appl Chem., 1992, 64(2), 227.

33. Tasev K, Karadjova I and Stafilov T, J Microchem., 2005, 149, 55-60.

34. Trung D Q, Anh C X, Trung N X, Yasaka Y, Fujita M and Tanaka M, Anal Sci., 2001, 17, i1219-i1222.

35. Tuzen M, Parlar K and Soylak M, J Hazard Mater, 2005, 121, 79-87.

36. Hasegawa S, Sato K, Ide K, Kobayashi T, Igarashi S and Naito K, J Japan Inst Met., 2000, 64(12), 1212-1217.

37. Uzun A, Soylak M and Elci L, Talanta, 2001, 54, 197-202.

38. Karami H, Mousavi M F, Yamini Y and Shamsipur M, Anal Chim Acta, 2004, 509, 89.

39. Muranyi Z and Papp L, J Microchem., 1998, 60, 134-142.

40. Perez-Jordan M Y, Soldevila J, Salvador A, Pastor A and de la Guardia M, J Anal At Spectrom., 1998, 13, 33.

41. Jos A, Mareno I, Gonzalez A G, Repetto G and Camean A M, Talanta, 2004, 63, 377-382.

42. de Pena Y P, Paredes B, Rondon W, Burguera M, Burguera J L, Rondon C, Carrero P and Capote T, Talanta, 2004, 64, 1351-1358.

43. Perez-Cid B, Rio-Segade S and Bendicho C, J Microchem., 1997, 55(3), 319-328.

44. Atanasova D, Stefanava V and Russeva E, Talanta, 1998, 45(5), 857-864.

45. van Staden J F and Botha A, Talanta, 1999, 49(5), 1099-1108.

46. Narin I and Soylak M, Anal Chim Acta, 2003, 493, 205.

47. Tuzen M and Soylak M, Anal Chim Acta, 2004, 504, 325-334.

48. Chanthai S, Suwamat N, Ruangviriyachai C and Danvirutai P, ASEAN Food J., 2007, 14, 181-196. 


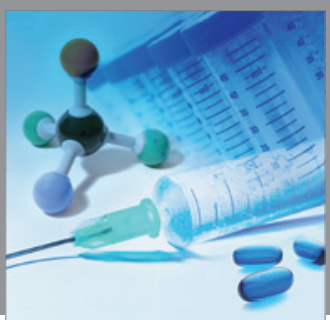

International Journal of

Medicinal Chemistry

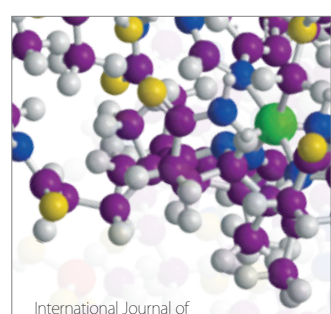

Carbohydrate Chemistry

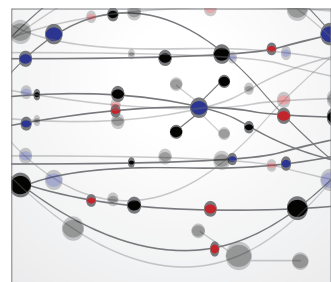

The Scientific World Journal
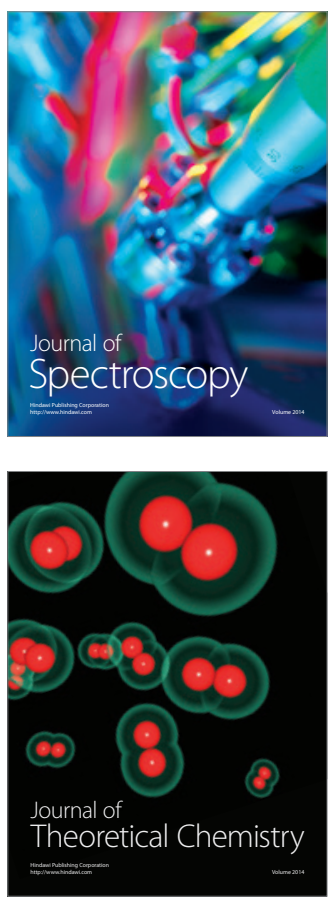
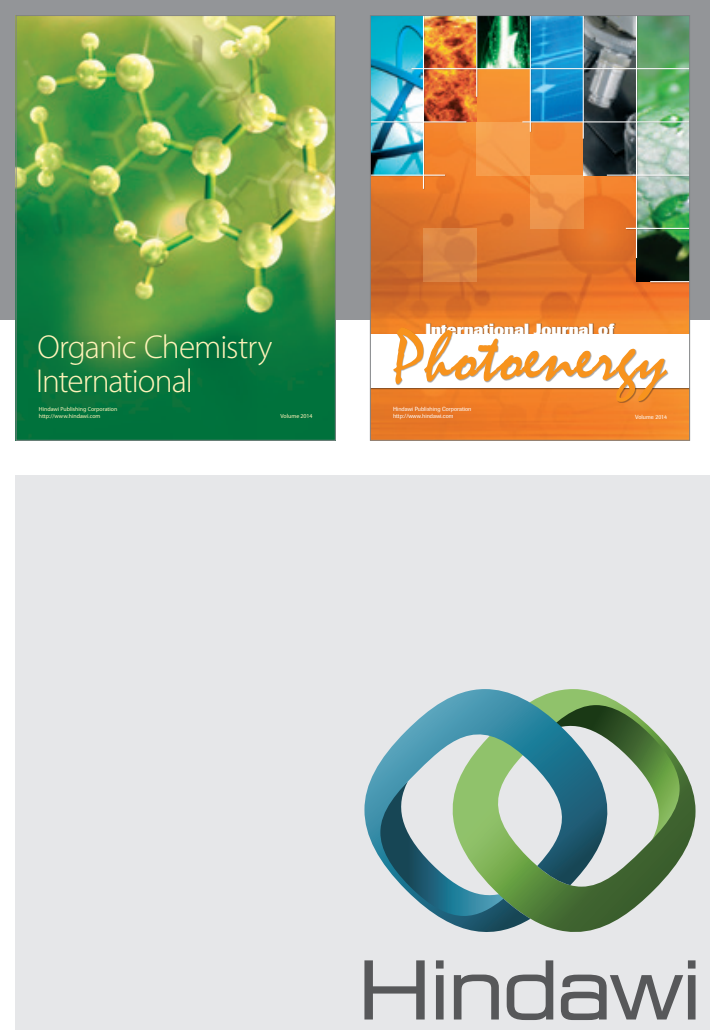

Submit your manuscripts at

http://www.hindawi.com
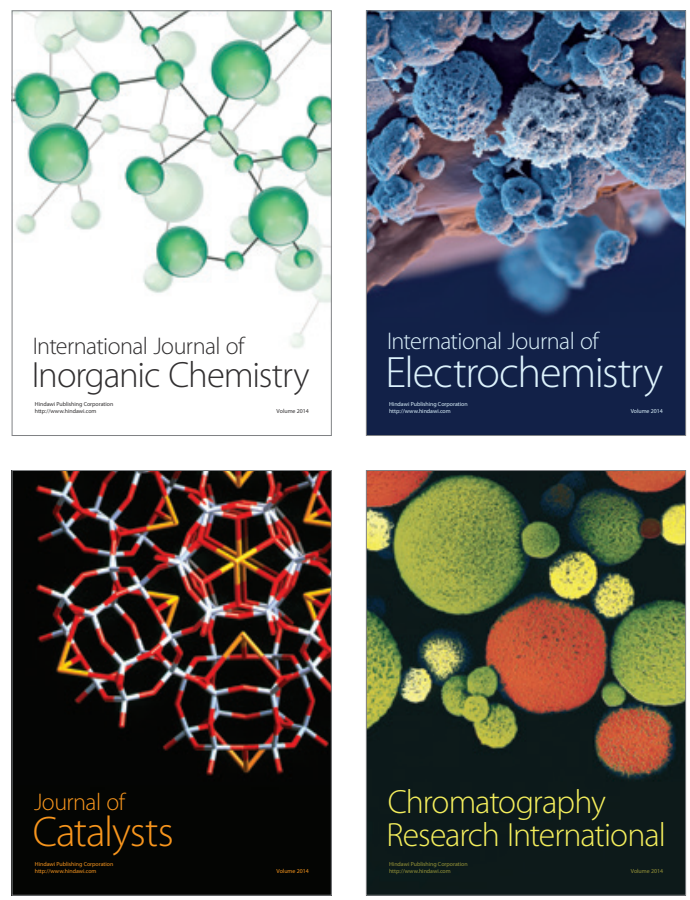
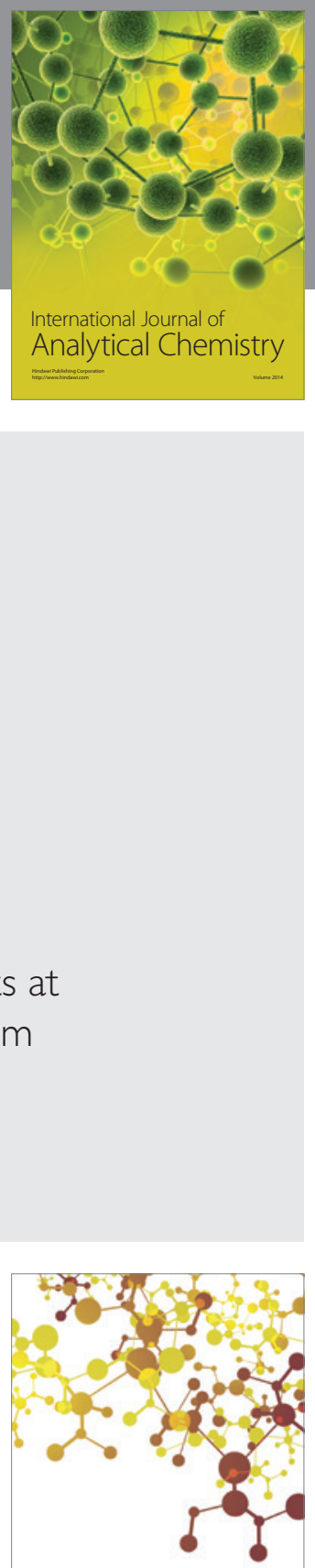

Journal of

Applied Chemistry
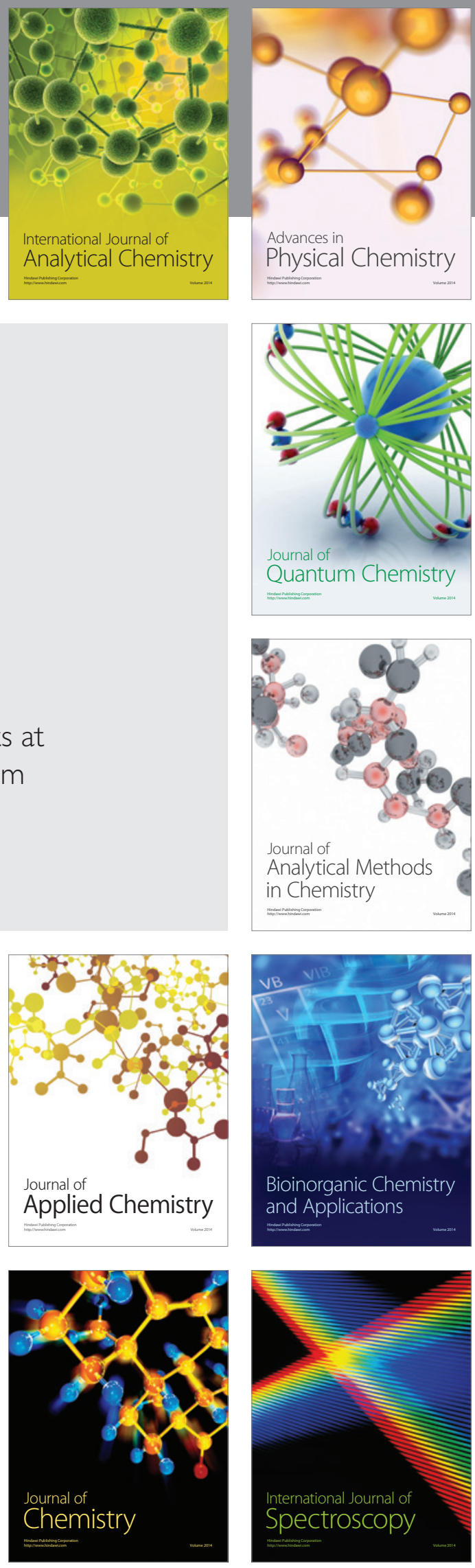